Indian J. Anim. HIth. (2019), 58(1) : 131-134

DOI: https://doi.org/10.36062/ijah.58.1.2019.131-134

\title{
ASSESSMENT OF HEAVY METALS IN INDIAN MAJOR CARPS
}

\author{
P. SINGH*, G. C. RANA AND B. N. PAUL ${ }^{1}$ \\ Vidyasagar University, AMT Department \\ Purba Midnapore-721 102 \\ West Bengal, India
}

\begin{abstract}
The present study determined the levels of arsenic and copper in muscle tissues of Indian Major Carp (Labeo rohita, Catla catla and Cirrhinus mrigala) of 500-1500 $\mathrm{g}$ of weight ranges. The fish samples were collected from Rahara fish farm of ICAR-Central Institute of Freshwater Aquaculture, North 24parganas and Mudialy Fishermen Co Operative Society fish farm, South 24 Parganas and estimated the health risk posed by fish ingestion. Heavy metals concentrations in fish were analyzed by using atomic absorption spectrophotometer. Arsenic content was found to be $0.17 \pm 0.02,0.87 \pm 0.03$ and $0.19 \pm 0.05(\mathrm{ppb})$ respectively in rohu, catla and mrigal which was significantly $(\mathbf{P}<0.05)$ higher in Catla catla. In the present work, the concentration of copper in the muscles of rohu, catla and mrigal was found to be $0.64 \pm 0.13,0.69 \pm 0.22$ and $0.25 \pm 0.01(\mathrm{ppm})$ respectively. Copper content did not differ significantly among rohu, catla and mrigal. Levels of heavy metals (arsenic and copper) were below the permissible limits of human health. Regular monitoring of heavy metals in fish tissue is required to check its contamination level in fish tissues reared in wastewater. Thus, the present study shows that the consumption of fish reared in wastewater is safe for human so far heavy metals like arsenic and copper are concerned.
\end{abstract}

Key words: Arsenic, Copper, Fish muscle, Indian major carp, Tolerable intake

Metals are unrelenting contaminants and they aggregate in soil, water, sediment and mostly, in trophic chains. Heavy metals are naturally occurring trace components of the aquatic habitats that have been increased tremendously due to domestic, industrial, mining and agricultural activities (Karbassi et al., 2006). Fish can be considered as one of the most significant bio-monitors in freshwater systems (Begum et al., 2005). For fish, the gills, skin and digestive tract are the most likely sites of uptake of water borne chemicals (Barlas, 1997). Fishes are major part of the human diet due to high protein and sufficient polyunsaturated fatty acids which are known to support good health, therefore, various studies have been taken worldwide on the contamination of different fish species by heavy metals (Rauf et al., 2009). Hence, it is important to monitor all potential contaminants of the ecosystem and its effect on food web to

*Corresponding Author

${ }^{1}$ Regional Research Centre of ICAR-CIFA, P.O.- Rahara, Kolkata-700 118, India 
ensure the food quality and safety (Andreji et al., 2006). Copper is an essential substance to human life, but in high doses it can cause liver and kidney damage, and stomach and intestinal irritation (Hubicki and Kolodynska, 2012). The Present study has been made to investigate the concentration of arsenic and copper in Indian Major Carps as there is worldwide concern about of contamination of aquatic organisms by metal concentration.

Seven numbers juveniles each of Labeo rohita, Catla catla and Cirrhinus mrigala were randomly collected from Rahara fish farm of ICAR-Central Institute of Freshwater Aquaculture and Mudialy Fishermen Co Operative Society. The collected samples were iced immediately and then taken for analyses. Sampling procedure and sample preparation was done as per (Sankar et al., 2010). Heavy metals analysis was done as per (AOAC, 2005). The samples were subjected to wet oxidation (digestion) with di-acid mixture of $\mathrm{HNO}_{3}$ and $\mathrm{H}_{2} \mathrm{SO}_{4}$ at the ratio of $3: 1(\mathrm{v} / \mathrm{v})$ at $<150^{\circ} \mathrm{C}$ until watery coloured solution appeared (Paul et al., 2014). It was transferred to a volumetric flask (100 mL capacity) and volume was made up to the mark with $2 \% \mathrm{HNO}_{3}$. This solution is then filtered through glass filter $(25 \mathrm{~mm}$ diameter and porosity $0.22 \mu \mathrm{m}$ ). Total arsenic was analyzed under Atomic Absorption Spectrophotometer coupled with Hydride Generator (Thermo Fisher, M Series; U.K.). Data were subjected to statistical analysis (Snedecor and Cochran, 1994) and the least significance difference (LSD) was used for comparison of the mean values.

Table 1 represents the concentrations of heavy metals in the samples tested. Arsenic content was found to be $0.17 \pm 0.02$, $0.87 \pm 0.03$ and $0.19 \pm 0.05(\mathrm{ppb})$ respectively in rohu, catla and mrigal, which was significantly $(\mathrm{P}<0.05)$ higher in catla. The concentrations of copper in the muscle tissues of rohu, catla and mrigal was found to be $0.64 \pm 0.13,0.69 \pm 0.22$ and $0.25 \pm 0.01$ $(\mathrm{ppm})$ and it was found to be nonsignificant among the three species.

Fishes are the simple and reliable biomarker of copper pollution of aquatic bodies (Lodhi et al., 2006). In the present study content of copper in rohu, catla and mrigal tissue was $0.64 \pm 0.13,0.69 \pm 0.22$ and $0.25 \pm 0.01$ (ppm) respectively (Table 1$)$. The copper concentration in muscle tissue varied from 2.12 to $27.94 \mu \mathrm{g} / \mathrm{g}$ for fishes from East Kolkata Wetlands (Kumar et al., 2011).

Table 1. Arsenic and copper content in Indian Major Carp

\begin{tabular}{lccc}
\hline Heavy metals & Labeo rohita & Catla catla & Cirrhinus mrigala \\
\hline Arsenic $(\mathrm{ppb})$ & $0.17^{\mathrm{a}} \pm 0.02$ & $0.87^{\mathrm{b}} \pm 0.03$ & $0.19^{\mathrm{a}} \pm 0.05$ \\
Copper $(\mathrm{ppm})$ & $0.64 \pm 0.13$ & $0.69 \pm 0.22$ & $0.25 \pm 0.01$ \\
\hline
\end{tabular}

Data presented as Mean \pm S.E, Superscripts ${ }^{a b}$ in a row differs significantly $(\mathrm{P}<0.05)$ 
Adhikari et al. (2008) calculated $14.7 \mu \mathrm{g} /$ person daily intake of copper through fish consumption which is based on the average copper content of the five fish species i.e. Labeo rohita, Catla catla, Cirrhinus mrigala, Oreochromis mossambicus and Cyprinus carpio. $7.59 \mu \mathrm{g} / \mathrm{g}$ level of copper was found in the body of fish collected from Pennar estuary, India (Ravanaiah and Murthy, 2010) and $0.40-0.59 \mu \mathrm{g} / \mathrm{g}$ in the tissues of fish from freshwater lake of Bhopal, India (Malik et al., 2010). Copper level in the muscle of catla was $0.48 \pm 0.14 \mu \mathrm{g} / \mathrm{g}$ dry weight (Adhikari et al., 2008). Samir and Ibrahim (2008) reported $2.80 \mathrm{ppm}$ of Cu in the muscle of Oreochromis niloticus collected from the Northern Delta lakes of Egypt.

Foata et al. (2009) reported that the fish collected from Presa river, France having $0.62-1.37 \mu \mathrm{g} / \mathrm{g}$ range of arsenic. The arsenic level of rohu and mrigal reported in this study was lower than the earlier reports (Foata et al., 2009; Kar et al., 2011). However, arsenic level in catla was within the similar

\section{REFERENCES}

Adhikari S, Ghosh L, Rai S and Ayyappan S, 2008. Metal concentrations in water, sediment, and fish from sewage-fed aquaculture ponds of Kolkata, India. Environ Monit Assess, 159: 217-230

Andreji J, Stanai I, Massanyi P and Valent M, 2006. Accumulation of some metals in muscles of five fish species from Lower Nitra River. J Environ Sci Eng, 41: 26072622

AOAC, 2005. Official methods of Analysis, $18^{\text {th }}$ edn., Association of Official Analytical Chemists, Washington, D.C. range of earlier worker (Kar et al., 2011). USEPA (2002) reported that an adromous nature and resident fish from Columbia River Basin contained $86 \%$ of total arsenic in their fillets in comparison to whole bodies for 10 numbers of species.

Total arsenic residues in muscle of rohu, catla and mrigal did not exceed the permissible limit of Indian Standard of 1ppm (MFPO, 1992; FSSAI, 2011). The permissible limit for copper set by WHO (2004) is $30 \mathrm{ppm}$. Total copper residues in IMC in the present study are also within the permissible limit (FSSAI, 2011). Thus, the present study shows that the consumption of fish reared in wastewater is safe for human beings.

Conflict of Interest: The author declares that they have no conflict of interest.

\section{ACKNOWLEDGEMENT}

The authors acknowledge the Director, ICAR-CIFA for providing the necessary facility to conduct the research work.

Begum A, Amin MN, Kaneco S and Ohta K, 2005. Selected elemental composition of the muscle tissue of three species of fish, Tilapia nilotica, Cirrhina mrigala and Clarias batrachus from the freshwater Dhanmondi Lake in Bangladesh. Food Chem, 93: 439-443

Barlas N, 1997. A pilot study of heavy metal concentration in various environments, fishes in the upper Sakarya River Basin, Turkey. Environ Toxicol, 14: 367-373

Foata J, Quilichini Y, Torres J, Pereira E, Spella MM et al., 2009. Comparison of arsenic and 
antimony contents in tissues and organs of Brown Trout Caught from the river Presa polluted by ancient mining practices and from the river Bravona in Corsica (France): A survey study. Arch Environ Conta Toxicol, 57: 581-589

FSSAI (Food Safety Standards Authority of India), 2011. Food Safety and Standards (Contaminants, toxins and residues), regulations, 2011, available at: http:// www.fssai.gov.in

Hubicki Z and Kolodynnska D, 2012 Selective Removal of Heavy Metal Ions from Waters and Waste Waters Using ion Exchange Methods. In: Kilislioglu, A., edn., Ion Exchange Technologies

Kar S, Maity JP, Jean JS, Liu CC, Liu CW et $a l ., 2011$. Health risks for human intake of aquacultural fish: Arsenic bioaccumulation and contamination. J Environ Sci Health, Part A, 46 (11): 12661273

Karbassi R, Bayati I and Maottar F, 2006. Origin and chemical portioning of heavy metals in riverbed sediments. Int J Environ Sci Tech, 3: 35-42

Kumar B, Mukherjee DP, Kumar S, Mishra M, Prakash D et al., 2011. Bioaccumulation of heavy metals in muscle tissue of fishes from selected aquaculture ponds in east Kolkata wetlands. Ann Biol Res, 2: 125-134

Lodhi HS, Khan MA, Verma RS and Sharma UD, 2006. Acute toxicity of copper sulphate to fresh water prawns. J Environ Biol, 27: 585-588

Malik N, Biswas AK, Qureshi TA, Borana K and Virha R, 2010. Bioaccumulation of heavy metals in ûsh tissues of a freshwater lake of Bhopal. Environ Monit Assess, 160: 267-276

MFPO (Meat Food Products Order), 1992.
Ministry of Agriculture, Govt. of India

Paul BN, Chand S, Das S, Singh P, Pandey BK et al., 2014. Mineral Assay in Atomic absorption Spectroscopy. The beats Natural Sci, 1: 1-17

Rauf A, Javed M and Ubaidullah M, 2009. Heavy metals level in three major carps (Catla Catla, Labeo rohita and Cirrhinus mrigala) from the river Ravi, Pakistan. Pakistan Vet J, 29: 24-26

Ravanaiah G and Narasimha Murthy CV, 2010. Accumulation of heavy metals in selected tissues of fish, Tilapia Mossambica collected from the Pennar Estuary. Life Sci Bull, 7(2): 217-222

Samir MS and Ibrahim MS, 2008. Assessment of heavy metals pollution in water and sediments and their effect on Oreochromis niloticus in the Northern Delta Lakes, Egypt. $8^{\text {th }}$ International Symposium on Tilapia in Aquaculture, Cairo, Central Lab for Aquaculture Research, Agricultural Research Center, Limnology dept.12-14 October 2008, 475-489

Sankar TV, Susheela M, Anandan R, Asha KK and Mohanty BP, 2010. Nutirent profiling of fish. ICAR-Central Institute of Fisheries Technology, Cochin, Kerala, India, pp1-61

Snedecor GW and Cochran W G, 1994. Statistical Methods. $8^{\text {th }}$ edn., Oxford and IBH Publishing CO. Pvt. Ltd., New Delhi

USEPA (US Environmental Protection Agency), 2002. Columbia River Basin Fish Contaminant Survey 1996-1998. EPA 910-R-02-006. U.S. Environmental Protection Agency, Region 10, Seattle, WA, USA

WHO, 2004. World Health Organization Guidelines for Drinking water. 2007. Quality. 3rd edn., Joint FAO/WHO Expert Committee on Food Additives, 1: 296-459

Article received on 20.04.2019 and accepted for publication on 23.05.2019 